\title{
TESTIS UNUS TESTIS NULLUS - the Testimony of Saint Ambrose
}

The activity of Saint Ambrose, the Archbishop of Milan, took place in the second half of the $4^{\text {th }}$ century after Christ. It was the time when the idea of Bishop Church was getting constituted, which was also referred to as monarchical episcopate. ${ }^{1}$ The special and superior role of a bishop who was deemed as a kind of an arbiter of spiritual life was one of its characteristics. He ensured discipline in his congregation imposing appropriate injunctions, adequate penance, and - if necessary - he punished. His duties also involved resolving disputes among the community members under his bishop care. ${ }^{2}$ Over time, the institution of au-

* Rev. Ph.D. in Law, Master of Sacred Theology; e-mail: karoladamczewski@student.kul. lublin.pl, ORCID ID: https:/ / orcid.org/0000-0003-1294-4458.

1 Saint Ambrose (Ambrosius Aurelius) is recognised as one of the four Doctors of the West Church. He was born in Trier around the year 340 in an old Roman Patrician family. His father, holding one of the most senior offices in the Empire, served as a prefecture prefect and also administrator of Spain, Gaul and Bithinia. Around 327 Ambrose, following the footsteps of his father, took office of the governor of Emilia and Liguria in the seat in Milan. He resigned from holding those state positions, when - unexpectedly and against his will - he was elected the Bishop of Milan by the faithful. This was approved by Emperor Valentian in December 374. He enjoyed common respect and authority. He saw the opportunity to restore the Roman Empire through promoting Christian values as well as joint cooperation and solidarity between the state and the Church. He was much involved in public activity and was regarded one of the closet advisers of emperors: Gratian, Valentinian II, Theodosius the Great. He was the author of many works on moral and ascetic themes as well as legal. Oxford Dictionary of the Christian Church, ed. F.L. Cross, E.A. Livingstone, Oxford-New York 2005, pp. 49-50.

2 C. Fantappiè, Storia del diritto canonico e delle istituzioni della Chiesa, Bologna 2011, p. 35; L. Loschiavo, Tra legge mosaica e diritto Romano. Il caso Indicia, la "Didascalia 
dientia episcopalis ${ }^{3}$ was developed, within which resolving a wide range of disputes, not only between Christians, became a regular competence of the bishop. ${ }^{4}$

It should be noted that in the ecclesial procedural practice, evidence from witness statements was given a prominent place. ${ }^{5}$ It concerned, in particular, its two aspects. First of all, testimony had a double status developed in the Jewish culture and adapted for the needs of Christianity, i.e. theological and judicial. ${ }^{6}$

The other essential element of the testimony derived from the Law of Moses was the requirement to submit it by at least two or three witnesses. ${ }^{7}$ Their statements had a fundamental importance. However, the role of witnesses was not merely to make statements. They also acted as accusers. In other words, the proceedings might be initiated on the grounds of charges brought to court by at least two witnesses - accusers, similarly to

Apostolorum" e la procedura del giudizio episcopale all'epoca del vescovo Ambrogio, in: "A Ennio Cortese". Scritti promossi da D. Maffei, ed. I. Birocchi et al., vol. 2, Roma 2001, p. 270.

3 L. Loschiavo, Figure di testimoni e modelli processuali tra antichità e primo Medioevo, Milano 2004, p. 53.

4 Despite the complexity and even the lack of clarity in the functioning of episcopalis audientia, one may point at certain characteristics of this institution in the ancient Church. Formal establishment of the bishop judiciary was effected under the Constitution issued by Emperor Constantine the Great in 318 (C. Th. 1,27,1). Its creation was connected with the will of the Church to obtain sovereignty in religious matters as well as the recognition of ecclesiastical tribunals that might hear cases of clergymen with no need to sue them in the state courts (privilegium fori), and also cases of lay people (episcopalis audientia). Cf. M.R. Cimma, A proposito delle Constitutiones Sirmondianae, in: Atti dell'Accademia Romanistica Costantiniana, vol. 10. Convegno internazionale in onore di Arnaldo Biscardi, Perugia 1995, pp. 359-389; M.R. Cimma, L'Episcopalis audientia nelle costituzioni imperiali da Costantino a Giustiniano, Torino 1989, pp. 5-9; S. Jóźwiak, Państwo i Kościót w pismach św. Augustyna, Lublin 2004, pp. 157-158; J. Śrutwa, Episcopalis audientia w Afryce rzymskiej, Roczniki Teologiczno-Kanoniczne 1981, vol. 28, no. 4. Historia Kościoła, pp. 183-187; I. Leraczyk, Episcopalis audientia, in: Leksykon tradycji rzymskiego prawa prywatnego. Podstawowe pojęcia, ed. A. Dębiński, M. Jońca, Warszawa 2016, pp. 136-137.

5 Episcopalis audientia as an institution of Roman law provided a clear legal basis for the bishop courts to act and resolve both civil and criminal cases of lay people, in general subject to the state judiciary. Cf. J. Śrutwa, Episcopalis..., p. 183; S. Jóźwiak, Państwo..., pp. 157-159.

6 G. Lanata, Confessione o professioné? Il dossier degli Atti dei martiri, in: L'aveu. Antiquite at Moyen Âge. Actes de la table ronde de Rome (28-30 mars 1984), Roma 1986, p. 139.

7 L. Loschiavo, Figure..., p. 53. 
the Jewish procedural law. ${ }^{8}$ Interestingly, the procedural requirement testis unus testis nullus, referred to a number of times in the New Testament, ${ }^{9}$ provided in a natural way the grounds to build up early Christianity. ${ }^{10}$ Nevertheless, it is noteworthy that as early as in the $4^{\text {th }}$ century, reference standards in Church began to change and the solutions typical of the Roman law were applied more often. ${ }^{11}$

In the adoption of the Roman legal culture into ecclesiastical legislation, particularly in the West, it was Saint Ambrose, the Bishop of Milan who had a special role to play. ${ }^{12}$ In this context, his letters, in which he reported some lawsuit appear to be particularly valuable. Ambrose performed a role of a judge in the case concerned Indicia, a virgin consecrated to God. Her trial became the main reason for Ambrose to write two letters to his subordinate, i.e. the Bishop of Verona. Ambrose pointed out the mistakes made in the lawsuit and questioned the lawfulness of the proceeding. Subsequently, while reviewing the case, he showed the right procedure for that kind of cases. ${ }^{13}$

The case of Indicia had its origins in rumours and unfair slanders. According to them, the virgin consecrated to God, was to break her vows of chastity, and, after delivering a baby, to kill her child. On the basis of uncertain and unproven information, Maximus reported to the Bishop of Verona, Syagrius, that Indicia committed a crime against chastity. The informer, due to the affinity between them, did not want to act as an official

8 Dt 19,15-21; “A single witness shall not suffice against a person for any crime or for any wrong in connection with any offense that he has committed. Only on the evidence of two witnesses or of three witnesses shall a charge be established."

9 P.D. Miller, Deuteronomy. Interpretation. A Bible Commentary for Teaching and Preaching, Louisville 1990, pp. 144-145; Deuteronomio. Nuova versione, introduzione e commento, ed. S. Paganini, I Libri Biblici. Primo Testamento 5, ed. G. Borgonovo, [Milano] 2011, p. 303.

10 Cf. Mt 18,15-16; Mt 26,59-61; Mc 14,55-59; 2 Cor 13,11; Tim 5,19, Heb 10,20; Io 8,17.

11 A. Gouron, "Testis unus, testis nullus" dans la doctrine juridique du XIIe siècle, in: Mediaeval antiquity, ed. A. Welkenhuysen, H. Braet, W. Verbeke, Mediaevalia Lovaniensia series 1, vol. 24, Leuven 1995, pp. 83-84; S. Puliatti, Giudizio di fatto e nuovi principi nel processo romano tardoantico. La regola "unus testis nullus testis", in: Principios generales del derecho. Antecedentes históricos y horizonte actual, ed. F. Reinoso-Barbero, Madrid 2014, pp. 145-148; A. Wacke, Unus testis, nullus testis. Entstehung und Überwindung des Dogmas vom legalen Beweismaß, Fundamina 1997, no. 3, pp. 49-52.

12 S. Ladier, Proces karny w Talmudzie ( $z$ zagadnień stosunku prawa procesowego do prawa karnego materjalnego w Talmudzie), Lwów 1933, p. 53.

13 L. Loschiavo, Figure..., p. 53. 
accuser. Then, two witnesses were appointed - Renatus and Leontius who made false statements against Indicia. Bishop Ambrose wrote: "Yet, at the same time as they devised the crime and set out (to omit no details) according to Leontius, they had joined Maximus and those others who spread the rumor." ${ }^{14}$ In response, Bishop Syagrius, despite the lack of sufficient evidence confirming the fault of the accused, ordered an inspection of Indicia by an expert midwife. Basing on the single testimony of the midwife, he ruled Indicia was guilty. In turn, Indicia appealed the conviction to Ambrose, the Bishop of Milan, who was Syagrius's superior. ${ }^{15}$

The first serious accusation regarding irregularities in the proceedings was the lack of a formal accuser as well as at least two reliable witnesses who might confirm them. In the introduction to his letter, Ambrose wrote reproachfully to Syagrius: "You set up in your court accusers of the same sort and witnesses who did not dare make a charge or bind themselves with the informer's role. So, you decided to judge the virgin by an examination, a virgin whom no one censured, no one brought to trial [...] you made your decision before the trial."16

Then, the Bishop of Verona was asked some concrete and cumbersome questions. They were to underline the importance of the committed mistakes, as Ambrose argued:

Where is the formality of inquiry, where is there provision for such a trial? If we consult the state laws, they demand an accuser; if the Church laws, we find: "On the word of two or three witnesses every word stands." Take as witnesses those who were not enemies two or three days ago, so that men in anger may not desire to harm the accused or, being harmed themselves, wish for vengeance. ${ }^{17}$

Not only did the words cited expressed the author's indignation over deficiencies made, but also proved his good command of legal procedures of the two legal systems. While speaking about the accuser, Ambrose made a reference to the rules of the Roman procedural law and the state

14 Cf. List Ambrożego do Syagriusza, 56,19-24; 57,1-4, in: Św. Ambroży z Mediolanu, Listy (36-69), vol. 2, transl. and footnotes P. Nowak, introduction and ed. J. Naumowicz, Kraków 2003, pp. 78-81.

15 List Ambrożego do Syagriusza, 56, pp. 70-71.

16 B. Wilanowski, Rozwój historyczny procesu kanonicznego, vol. 1. Proces kościelny w starożytności chrześcijańskiej, Wilno 1929, p. 54.

17 List Ambrożego do Syagriusza, 56, 1, pp. 70-71. 
courts where the case was initiated once the indictment was brought by an accusator. ${ }^{18}$ Luca Loschiavo claimed, however, this was not about giving a detailed manner of proceeding by Roman judges. His intention was rather to emphasise meticulousness and caution they showed while issuing convictions, even though they were not aware of their responsibility before God, contrary to Church judges delivering judgments within audientia episcopalis. ${ }^{19}$ Interestingly, in the aforementioned passage, the author confronted a construct of Roman law with the Jewish requirement of procedural law which laid down that two or three witnesses were to file charges. The institution of a witness-accuser, with roots going back to the Law of Moses, and cited by Ambrose, was indicated as lex Ecclesiae. ${ }^{20}$ It is important to point out that at that time the requirement for double testimony had already been applicable under Roman law as introduced by the Constitution of Emperor Constantine the Great in the year 334, ${ }^{21}$ which then, in the Middle Ages, took the form of the well-known rule testis unus testis nullus. ${ }^{22}$ Significantly, Ambrose reprimanding his subordinate for the lack of prudence in the conducted case referred, among others, to the biblical case of Naboth, ${ }^{23}$ who was a victim of court crime - the story of falsely accused Susanna ${ }^{24}$ and Christ's trial. ${ }^{25}$ The Bishop of Milan wrote as follows:

18 Ibidem, 56, 1, pp. 70-71.

19 W. Litewski, Rzymski proces karny, Kraków 2003, pp. 8-10.

20 L. Loschiavo, Tra legge..., pp. 276-278.

21 B. Wilanowski, Rozwój historyczny .., pp. 114-116.

22 C. 4,20,9: Imp. Constantinus Augustus ad Iulianum praesidem. Iurisiurandi religione testes prius, quam perhibeant testimonium, iam dudum arctari praecepimus, et ut honestioribus potius fides testibus habeatur. Simili more sanximus, ut unius testimonium nemo iudicum in quacumque causa facile patiatur admitti. et nunc manifeste sancimus, ut unius omnino testis responsio non audiatur, etiamsi praeclarae curiae honore praefulgeat. ("We previously ordered that witnesses prior to testifying are bound to take a solemn oath and more trust should be placed with a witness of a more dignified status. Likewise, we legitimised that, no judge should easily admit the taking of evidence of one person only. Now we clearly establish that, testimony by only one witness shall not be heard at all, even if such a witness enjoyed the respect of the famous curia. November the 25th 334, in Nisz, during the consulate of Optat and Paulin."); translated by the author.

23 Cf. J. Misztal-Konecka, Testis, in: Leksykon tradycji rzymskiego prawa prywatnego. Podstawowe pojęcia, ed. A. Dębiński, M. Jońca, Warszawa 2016, pp. 368-369; K. Burczak, A. Dębiński, M. Jońca, Łacińskie sentencje i powiedzenia prawnicze, Warszawa 2013, p. 297.

24 Cf. 1 Reg 21,10-13.

25 Cf. Dn 13,44-60. 
I have been horrified from the first at the calumny, for I realized that no verdict was intended, but that they wanted harm done to a girl, demanding the inspection and visitation of a maiden and not removing a charge of any sort. Who would not realize that a case fraudulently framed from the first was to remain inconsistent and not in conformity with itself? [...] Those who said that they had heard the rumor were called to the church, whereupon they betrayed Renatus and Leontius, those, "two men of iniquity" whom Jezabel opposed, Daniel convicted, and the Jewish people suborned, so that by false testimony they assailed the very Author of their life. ${ }^{26}$

Those words related directly to well-known biblical stories where false witnesses played a negative though a key role as they contributed to imposing death sentences on innocent persons. Saint Ambrose explicitly evaluated the credibility of the two persons bringing an indictment against Indicia as duos illos iniquitatis viros, comparing their meanness to wickedness and perversity of the witnesses testifying against Naboth, Susanna and Christ. ${ }^{27}$

The Bishop of Milan, while investigating the case, proved that Maximus, bringing accusation based on two uncertain testimonies, did not meet the requirements incumbent on the accuser. The two witnesses in the case, having been heard, appeared not credible. The first hearing revealed contradiction in their statements and gave grounds to regard them as false witnesses.

Yet, at the same time as they devised the crime and set out (to omit no details) according to Leontius, they had joined Maximus and those others who spread the rumor. Yet, when they stood in my court and I questioned them on the history of the case from the beginning, they related different discordant details, being divided not by space but by falsehood. ${ }^{28}$

Further in the letter, the author indicated that on a subsequent day set for the trial neither the accuser nor the witnesses designated by him appeared. The hearing of three other witnesses confirmed the judge's

26 Cf. Act 3,15; Mt 26,59-60.

27 List Ambrożego do Syagriusza, 56, 23, p. 79.

28 Cf. Św. Ambroży z Mediolanu, Historia Nabota, transl., introduction and ed. M. Kozera, Sandomierz 1985; B.S. Jackson, Susanna and the Singular History of Singular Witnesses, Acta Juridica 1977 - Essays in Honour of Ben Beinart, pp. 37-54; G. Rosadi, Il processo di Gesù, Firenze 1933, pp. 273-294. 
assumption on a false nature of the indictment. Both Maximus and the two false witnesses were found guilty of slander and convicted. ${ }^{29}$

Many years of the Jewish tradition imposed poena talionis if during the trial the false of the testimony-accusation was proven. ${ }^{30}$ The new Christian spirit, however, by its nature averse to any form of revenge, provided, under certain circumstances, even for exclusion from the community. ${ }^{31}$ Ambrose, concluding the proceedings in Indicia's case, wrote to Syagrius:

The sentence so involved Maximus and Renatus and Leontius that hope of their return [to the sacraments] was held out only for Maximus if he corrected his error; and Renatus and Leontius remained excommunicated unless, perhaps, proving their remorse and daily deploring their deed, they showed themselves worthy of mercy. ${ }^{32}$

Exclusion that was initially temporary and meant to bring the sinner to penitence and conversion, became permanent if in their conduct there was no expected improvement. ${ }^{33}$

The letters of the Bishop of Milan to Syagrius provided a valuable message. They revealed procedural structures applied in the first centuries in Church, including adapting from the Talmudic tradition the Old Testament person of a witness-accuser as well as the procedural requirement testis unus testis nullus. ${ }^{34}$ On the other hand, they indicated a slow,

29 List Ambrożego do Syagriusza, 56, 19, p. 78.

30 B. Wilanowski, Rozwój historyczny ..., pp. 53-55.

31 Cf. Dt 19,18-19: “The judges must make a thorough investigation, and if the witness proves to be a liar, giving false testimony against a fellow Israelite, then do to the false witness as that witness intended to do to the other party. You must purge the evil from among you. The rest of the people will hear of this and be afraid, and never again will such an evil thing be done among you."

32 C. Fantappiè, Storia..., pp. 38-39.

33 Excommunication is one of the most serious penalty in Church, imposed due to some grave offence. The guilty is excluded from the community and deprived of the rights to benefit from spiritual goods, sacraments, in particular. Cf. M. Myrcha, Prawo karne. Komentarz do Piątej Księgi Kodeksu Prawa Kanonicznego, vol. 2. Kara, part 1, Warszawa 1960, pp. 112-115.

34 C. Fantappiè, Storia..., pp. 38-40; L. Loschiavo, Figure..., pp. 58-59; L. Loschiavo, "Non est inter vos sapiens quisquam, qui possit iudicare inter fratrem suum?" Processo e giustizia nel primo cristianesimo dalle origini al vescovo Ambrogio, in: Ravenna Capitale. Giudizi, giudici e norme processuali in Occidente nei secoli IV-VIII, vol. 1. Saggi, ed. G. Bassanelli Sommariva, S. Tarozzi, P. Biavaschi, [Santarcangelo di Romagna] 2015, pp. 67 ff. 
though inevitable process of the opening of Church to the institutions of Roman law. It turned out that applying Roman law by the bishops did not contravene the Holy Scriptures, neither did it threaten Christians' salus animae. Moreover, the case of Indicia provided a clear instance that the two legal traditions showed at times striking convergence and mutual inspiration. ${ }^{35}$

For the problem in question, the manners of providing evidence were of crucial importance. The most serious accusations made by the Bishop of Milan against his subordinate from Verona concerned evidence issues. The point was that there was no verification of the consistency of the two testimonies and that there was the preference of one single proof from the examination carried out by a midwife over others. It was therefore a clear infringement of the procedural rule testis unus testis nullus, which before it had been announced by Constantine the Great in 334 as commonly binding, had been already applicable in the legal Jewish and Christian traditions for centuries.

As L. Loschiavo rightly noted, the rigorous injunction from the Gospel: sit autem sermo vester: est est, non non ${ }^{36}$ might not always be sufficient enough while hearing complex and difficult cases of human lives to bring smoothly each Church dispute to its end. Therefore, references to the legal solutions of Roman law were both beneficial and necessary. ${ }^{37}$

\section{Bibliography}

\section{Sources}

Corpus Iuris Civilis, vol. 2. Codex Iustinianus, ed. P. Krüger, Berolini 1954.

Pismo Święte Starego i Nowego Testamentu w przekładzie z języków oryginalnych, Biblia Tysiaclecia, ed. A. Jankowski, L. Stachowiak, K. Romaniuk, Poznań-Warszawa 1980.

\section{Literature}

Ambroży z Mediolanu św., Listy, vol. 2, transl. and footnotes P. Nowak, introduction and ed. J. Naumowicz, Kraków 2003.

Ambroży z Mediolanu św., Historia Nabota, transl., introduction and ed. M. Kozera, Sandomierz 1985.

\footnotetext{
35 Deuteronomio. Introduzione, traduzione, commento, ed. G. Papola, Milano 2011, p. 228.

36 L. Loschiavo, Tra legge..., p. 276.

37 Mt 5,37.
} 
Burczak K., A. Dębiński, M. Jońca, Łacińskie sentencje i powiedzenia prawnicze, Warszawa 2013.

Cimma M.R., L'Episcopalis audientia nelle costituzioni imperiali da Costantino a Giustiniano, Torino 1989.

Cimma M.R., A proposito delle Constitutiones Sirmondianae, in: Atti dell'Accademia Romanistica Costantiniana, vol. 10. Convegno internazionale in onore di Arnaldo Biscardi, Perugia 1995.

Deuteronomio. Introduzione, traduzione, commento, ed. G. Papola, Milano 2011.

Deuteronomio. Nuova versione, introduzione e commento, ed. S. Paganini, I Libri Biblici. Primo Testamento 5, ed. G. Borgonovo, [Milano] 2011.

Fantappiè C., Storia del diritto canonico e delle istituzioni della Chiesa, Bologna 2011.

Gouron A., "Testis unus, testis nullus" dans la doctrine juridique du XIIe siècle, in: Mediaeval antiquity, ed. A. Welkenhuysen, H. Braet, W. Verbeke, Mediaevalia Lovaniensia series 1, vol. 24, Leuven 1995.

Jackson B.S., Susanna and the Singular History of Singular Witnesses, Acta Juridica 1977 - Essays in Honour of Ben Beinart.

Jóźwiak S., Państwo i Kościót w pismach św. Augustyna, Lublin 2004.

Ladier S., Proces karny w Talmudzie (z zagadnień stosunku prawa procesowego do prawa karnego materjalnego w Talmudzie), Lwów 1933.

Lanata G., Confessione o professioné? Il dossier degli Atti dei martiri, in: L'aveu. Antiquite et Moyen Âge. Actes de la table ronde de Rome (28-30 mars 1984), Roma 1986.

Leksykon tradycji rzymskiego prawa prywatnego. Podstawowe pojęcia, ed. A. Dębiński, M. Jońca, Warszawa 2016.

Leraczyk I., Episcopalis audientia, in: Leksykon tradycji rzymskiego prawa prywatnego. Podstawowe pojęcia, ed. A. Dębiński, M. Jońca, Warszawa 2016.

Litewski W., Rzymski proces karny, Kraków 2003.

Loschiavo L., Figure di testimoni e modelli processuali tra antichità e primo Medioevo, Milano 2004.

Loschiavo L., "Non est inter vos sapiens quisquam, qui possit iudicare inter fratrem suum?" Processo e giustizia nel primo cristianesimo dalle origini al vescovo Ambrogio, in: Ravenna Capitale. Giudizi, giudici e norme processuali in Occidente nei secoli IV-VIII, vol. 1. Saggi, ed. G. Bassanelli Sommariva, S. Tarozzi, P. Biavaschi, [Santarcangelo di Romagna] 2015.

Loschiavo L., Tra legge mosaica e diritto romano. Il caso Indicia, la "Didascalia Apostolorum" e la procedura del giudizio episcopale all'epoca del vescovo Ambrogio, in: "A Ennio Cortese". Scritti promossi da D. Maffei, ed. I. Birocchi et al., vol. 2, Roma 2001.

Misztal-Konecka J., Testis, in: Leksykon tradycji rzymskiego prawa prywatnego. Podstawowe pojęcia, ed. A. Dębiński, M. Jońca, Warszawa 2016.

Miller P.D., Deuteronomy. Interpretation. A Bible Commentary for Teaching and Preaching, Louisville 1990. 
Odrobina L., La maxime: "Unus testis nullus testis" ou le témoignage de l'évêque au IVe siècle, Augustinianum 2003, vol. 43, no. 1.

Oxford Dictionary of the Christian Church, ed. F.L. Cross, E.A. Livingstone, OxfordNew York 2005.

Puliatti S., Giudizio di fatto e nuovi principi nel processo romano tardoantico. La regola "unus testis nullus testis", in: Principios generales del derecho. Antecedentes históricos y horizonte actual, ed. F. Reinoso-Barbero, Madrid 2014.

Rosadi G., Il processo di Gesù, Firenze 1933.

Śrutwa J., Episcopalis audientia w Afryce rzymskiej, Roczniki Teologiczno-Kanoniczne 1981, vol. 28, no. 4. Historia Kościoła.

Wacke A., Unus testis, nullus testis. Entstehung und Überwindung des Dogmas vom legalen Beweismaß, Fundamina 1997, no. 3.

Wilanowski B., Rozwój historyczny procesu kanonicznego, vol. 1. Proces kościelny w starożytności chrześcijańskiej, Wilno 1929.

\section{Su m mary}

Saint Ambrose, the Bishop of Milan, played a key role in the adoption of the Roman legal culture into ecclesiastical legislation, particularly in the West in the second half of the $4^{\text {th }}$ century. In this context, his letters reporting some lawsuit appear to be of special value. The case involved Indicia, a virgin consecrated to God. Ambrose pointed out the mistakes committed in the investigation and he questioned the lawfulness of the proceedings. While reviewing the case, he showed to his subordinate what appropriate conduct was to have been undertaken in this kind of case. He especially emphasized the necessity to maintain the procedural requirement of consistent testimony of at least two witnesses. Significantly, the legal rule cited by the Bishop of Milan principle testis unus testis nullus, before it was announced by Constantine the Great in 334, had already existed in the Judeo-Christian legal tradition.

Key words: testis unus testis nullus, Saint Ambrose, witness

\section{TESTIS UNUS TESTIS NULLUS - ŚWIADECTWO ŚW. AMBROŻEGO Streszczenie}

Święty Ambroży, biskup Mediolanu, odegrał znaczącą rolę w przyswajaniu rzymskiej kultury prawnej w prawodawstwie kościelnym, zwłaszcza na Zachodzie w drugiej połowie IV w. W tym kontekście wydają się cenne jego listy, 
w których zrelacjonował przebieg pewnej sprawy sądowej. Przypadek dotyczył Indycji, poświęconej Bogu dziewicy. Ambroży wytknął w nich błędy, jakie popełniono $\mathrm{w}$ procesie, oraz podważył zasadność przeprowadzonego postępowania. Ponownie badając sprawę wskazał swemu podwładnemu, jak należało prawidłowo postąpić $\mathrm{w}$ tego rodzaju przypadku, podkreślając szczególnie konieczność zachowania procesowego wymogu przynajmniej dwóch zgodnych zeznań świadków. Znamienne jest, iż przytoczona przez biskupa mediolańskiego procesowa reguła testis unus testis nullus, zanim została ogłoszona przez Konstantyna Wielkiego w 334 r., jako powszechnie obowiązująca, istniała już od wieków w prawnej tradycji judeo-chrześcijańskiej.

Słowa kluczowe: testis unus testis nullus, św. Ambroży, świadek

\section{TESTIS UNUS TESTIS NULLUS - СВИДЕТЕЛЬСТВО СВ. АМВРОСИЯ Резюме}

Святой Амвросий, епископ Миланский, сыграл значительную роль в ассимиляции римской правовой культуры в церковном законодательстве, особенно на Западе во второй половине IV века. В этом контексте представляются ценными его письма, в которых он сообщил о ходе некоего судебного разбирательства. Дело касалось Индиции, посвященной Богу девственницы. Амброзий указал в них на ошибки, допущенные в ходе судебного разбирательства, и подорвал законность разбирательства. Пересматривая дело, он указал своему подчиненному, как следовало правильно действовать в этом случае, подчеркнув, в частности, необходимость соблюдения процедурного требования, по крайней мере, двух совместимых свидетельских показаний. Знаменательно, что процедурное правило testis unis testis nullus, на которое ссылался епископ Миланский, до того, как оно было провозглашено Константином Великим в 334 г. как общеобязательное, уже веками существовало в иудейско-христианской правовой традиции.

Ключевые слова: testis unus testis nullus, св. Амвросий, свидетель 
